Research Report No. 16/2013

\title{
Reconstructing Fuller's Argument Against Legal Positivism
}

Dan Priel

Osgoode Hall Law School of York University, dpriel@osgoode.yorku.ca

Follow this and additional works at: http:// digitalcommons.osgoode.yorku.ca/clpe

\section{Recommended Citation}

Priel, Dan, "Reconstructing Fuller's Argument Against Legal Positivism" (2013). Comparative Research in Law \& Political Economy. Research Paper No. 16/2013.

http://digitalcommons.osgoode.yorku.ca/clpe/265 


\section{OSGOODE}

OSCOODE HALL LAW SCHOOL

YOR K UN I VERSITY

\section{OSGOODE HALL LAW SCHOOL}

Comparative Research in Law \& Political Economy

RESEARCH PAPER SERIES

Research Paper No. 16/2013

\section{Reconstructing Fuller's Argument against Legal Positivism}

Dan Priel

Editors:

Peer Zumbansen (Osgoode Hall Law School, Toronto, Director Comparative Research in Law and Political Economy)

John W. Cioffi (University of California at Riverside)

Leeanne Footman (Osgoode Hall Law School, Toronto, Production Editor) 


\title{
ReConstructing FULLER’S ARGuMENT AGaINST LeGal Positivism
}

\author{
Dan Priel ${ }^{*}$
}

\begin{abstract}
The purpose of this essay is to offer a reconstruction of Lon Fuller's critique of Hart's legal positivism. I show that contrary to the claims of Fuller's many critics, one can reconstruct from his work a clear and powerful argument against legal positivism, at least in the guise found in the work of H.L.A. Hart. The essence of the argument is that Fuller's principles of legality posit that the same considerations that count for law's excellence are relevant also for the determining what counts as law. I contrast this view with Hart's legal positivism, which acknowledged that the principles of legality are relevant for law's excellence, but considered them irrelevant for determining the question what counts as law. In contrast to Fuller's view, this view looks arbitrary, and-a point on which I focuscompletely undefended. And yet, despite the many years since Fuller presented his arguments against legal positivism, this argument has not been adequately answered. I conclude that even if Fuller's arguments are answerable, they are yet to be answered.
\end{abstract}

\section{The Unknown Fuller}

According to the received opinion among analytic legal philosophers the only thing useful one can learn from reading Lon Fuller is how to avoid the mistakes he committed. One could fill many a paragraph with examples of anti-Fuller invective found in jurisprudential literature, complaining on the confusion of his writings, on the implausibility of his ideas, and-particularly relevant to the present essay-on how badly wrong he got others' views. ${ }^{1}$ I therefore commit professional suicide by

*Associate Professor, Osgoode Hall Law School, York University. I thank Alon Harel, Charles Barzun, Mike Giudice and students in his graduate seminar, and an anonymous referee for their comments on earlier versions of this essay.

${ }^{1}$ Thus, for instance, Brian Leiter and Leslie Green have written about the "famously muddled Lon Fuller." Leslie J Green \& Brian Leiter, letter to the editor, "H.L.A. Hart and "The Concept of Law'" Times Literary Supp, March 11, 2005, at 15, 15. Writing again, this time alone, Leiter complained of Fuller's "spectacular confusions [that] may have poisoned the minds of a whole generation of law students." Brian Leiter, "The Radicalism of Legal Positivism" (2009) 66 Nat'l Law Guild Rev 165 at 165. Not to be outdone Matthew Kramer has accused Fuller of "flirtation with Nazism"! Matthew H Kramer, In Defense of Legal Positivism: Law without Trimmings (Oxford: Oxford University Press, 1999) at $114 \mathrm{n}$ 3. (For the record, Kramer cites a source for this allegation, but it does not support his claim; and as it happens, already in Lon L Fuller, The Law in Quest of Itself (Chicago: Foundation Press, 1940) at 122, Fuller wrote of the "disasters which engulfed Spain and Germany" in relation to their political upheavals.) The interested reader can find additional examples of this attitude towards Fuller in Sundram Soosay, "Rediscovering Fuller and Llewellyn: Law as Custom and Process" in Maksymilian Del Mar, ed, New Waves in Philosophy of Law (London: Palgrave 
openly declaring I consider The Morality of Law, despite unquestionable flaws, a better book than The Concept of Law. Or, since "good" is such a thick concept, that it is the more insightful one. ${ }^{2}$ That this has not been noticed by others I attribute to two facts. One is the tendency of philosophers to focus on "analytical" style over substance, what David Luban once called, a bit harshly but rather aptly, "liberation through constipation." ${ }^{3}$ Those works that abide by certain standards of orderliness, conceptual neatness, and certain stylistic dryness are often deemed "better" than works that do not score so well by these standards, even if what one finds in these neatly-argued writings is rather banal, or worse. Hart's book, which is more restrained in its style than Fuller's, is just a better fit for the mould of what a book of analytic philosophy should look like. (That is not to say the arguments in The Concept of Law are in fact clear. Dig a bit beneath the surface and the semblance of clarity disappears.) Fuller's book admittedly feels at times a bit all over the place, and his writing style can be florid. But though all this can be frustrating, Fuller is hardly ever obscure. And though not everything he said is convincing, when properly restrained, his ideas are interesting and original. The second reason for Fuller's bad reputation, no doubt related to the first, is that he is, in fact, not much read. Perhaps because of the assumption that he is deeply confused and misguided, there seems to be a prevailing view that one need not pay much attention to his work. It is enough to get the general drift-he spoke of "purpose," "internal morality," "legality," he wrote nice fables that are useful for introducing jurisprudence to beginners-but his work does not merit careful study. Judging by citations, legal philosophers only read the second chapter of The Morality of Law (which, lively though it is, is by no means the most important chapter in the book), and his Harvard Law Review response to Hart. The rest of his work in jurisprudence is largely unknown.

Now, of course, to show that Fuller is ignored is one thing, to show that he should not be, is quite another. To that end I mention here three examples from recent work by prominent legal philosophers, all self-styled legal positivists, who advance ideas that have been anticipated in Fuller's work, without any apparent awareness of this fact. In a contribution to a symposium on the Hart-Fuller debate Leslie Green challenged Fuller for not "paus[ing] to consider ... [whether] the Humean thesis" on the separation of is and ought "is incorrect." "Green seems

Macmillan, 2011) 31 at 32-33. Soosay's essay, like the present one, seeks to challenge this prevailing view.

${ }^{2}$ I say more on this in Dan Priel, "Institutional Morality and the Rule of Law" (unpublished manuscript).

3 David Luban, "Rediscovering Fuller's Legal Ethics" (1998) 11 Geo J Legal Ethics 801 at 803.

${ }^{4}$ Leslie Green, "Legal Positivism and the Inseparability of Law and Morals" (2008) 83 NYU L Rev 1035 at 1045. 
unaware of the fact that Fuller has written extensively on the issue on many occasions, that he has rejected the Humean thesis at least as early as his 1940 book The Law in Quest of Itself, 5 and has later participated in exchanges on the matter with Morris Cohen and Ernest Nagel. ${ }^{6}$

My second example comes from Andrei Marmor. A central aspect of his jurisprudential thinking is that laws are grounded in social conventions, and more specifically that " $[t]$ he rules of recognition, like the rules of chess, determine what the practice is. ... They determine what constitute the practice and prescribe modes of conduct within it."7 Compare this to Fuller, who in describing the forms of social order like "contract, adjudication, the majority principle, and the three-strike, fourball rule," tells us that "although we make them, they help to make us what we are, man's dependence on society being what it is." Offering an early articulation of the idea of the internal morality of practices, Fuller says that it is these rules that create the game of football, thus allowing us to say that it is a "good game," they also create internal standard for evaluating the practice itself: they allow us to say something like "[f]ootball will become impossible if this sort of thing is allowed to go on."

Perhaps the most striking example is Scott Shapiro's recent book Legality. Fuller is mentioned in the book, but as usual, he is called only to perform his bit part, once in relation to his debate with Hart, and once more in the context of his principles of legality. ${ }^{9}$ What one does not find in Shapiro's book is any reference to the fact that Fuller expressed ideas that bear, at the very least, unmistakable family resemblance to his planning theory of law. Consider the following statements:

I think that in the history of the common law we have an example which teaches how a social institution may derive its integrity and vitality from the same spirit of consultation as that which animates the discussion of two friends sharing a problem together. ${ }^{10}$

\footnotetext{
${ }^{5}$ Fuller, supra note 1 at $5-12$.

${ }^{6}$ See e.g. Lon L Fuller, "Human Purpose and Natural Law" (1956) 53 J Phil 697 at 697 ("it is my thesis that when we accept the full consequences that flow from a view which treats human action as goal-directed, the relation between fact and value assumes an aspect entirely different from that implied in the alleged 'truism' that from what is nothing whatever follows as to what ought to be."). Later in the same essay Fuller also rejects the Humean view that only reasoning about means is rational. See ibid at 702. For more on this aspect of Fuller's thought see Kenneth I Winston, "Is/Ought Redux: The Pragmatist Context of Lon Fuller's Conception of Law" (1988) 8 Oxford J Legal Stud 329.

${ }^{7}$ Andrei Marmor, Philosophy of Law (Princeton: Princeton University Press, 2011) at 82. I do not think this characterization of the rule(s) of recognition is consistent with Hart's, but that is a separate matter.

${ }^{8}$ Fuller, supra note 6 at 704.

${ }^{9}$ Scott J Shapiro, Legality (Cambridge: Harvard University Press, 2011) at 252-54, 39296.

${ }^{10}$ Fuller, supra note 6 at 703 .
} 
The engage in effective social behavior men need the support of intermeshing anticipations that will let them know their opposite numbers will do.... ${ }^{11}$

To perceive the distinction between the office of boss and that of lawgiver we have to go behind the quality or generality and ask why it has been thought that law must take the form of general rules. The answer is a relatively simple one: The law does not tell a man what he should do to accomplish specific ends set by the lawgiver; it furnishes him with base lines against which to organize his life with his fellows. ${ }^{12}$

The real point of this essay is not just to say "Fuller was there first" (and, at least sometimes, said it better). Rather, I want to argue that even the parts of his work that do get read are often read rather superficially, and that when considered more carefully, one can reconstruct from them a simple but powerful argument that clearly challenges Hart's and Hart-inspired legal positivism. Even if that argument can ultimately be answered, it cannot be breezily dismissed as confused; more importantly, to the best of my knowledge, it has not, in fact, been adequately answered. As the argument develops straightforwardly below, I will not summarize it here. All I will say upfront is that though it is based on The Morality of Law it does not hang on the question whether the principles of legality are a form of morality, or on Fuller's claim that there is often a connection between the law's internal and the external morality. I happen to think that when properly understood Fuller was right on both counts, but what I say below does not depend on these claims being true.

I will demonstrate my claim by considering a recent essay by John Gardner. ${ }^{13}$ Most of Gardner's short essay is dedicated to a comparison of Hart's work with Fuller's. Much of it is dedicated to a close reading of Hart's works, and though I disagree with Gardner's interpretation on various points, there can be no doubt that it is based on deep and sympathetic familiarity with Hart's work. The same cannot be said of Gardner's treatment of Fuller. ${ }^{14}$ Though he attributes many claims to

${ }^{11}$ Lon L Fuller, "Human Interaction and the Law" (1969) 14 Am J Juris 1 at 2.

${ }^{12}$ Ibid at 24.

${ }^{13}$ John Gardner, "Hart on Legality, Justice and Morality" (2010) 1 Jurisprudence 253. NE Simmonds, "Reply: The Nature and Virtue of Law" (2010) 1 Jurisprudence 277 at 28183, which responds to Gardner's essay does not address the issues I consider in this essay.

${ }^{14}$ Though my essay is not concerned with Dworkin, several statements in Gardner's essay are also very inaccurate readings of Dworkin. Consider one example: Gardner writes: "Dworkin ... tried to persuade us ... that law's inner morality (viz the ideal of legality) is its whole morality." Gardner, supra note 13 at 264. That is clearly false. Dworkin has argued that legality (by which, incidentally, Dworkin does not refer to Fuller's principles) is the unique morality of law, not that it is the whole of it. Almost everything Dworkin has written on jurisprudence is inconsistent with Gardner's claim. For a brief demonstration: "We can sensibly think that though the law rejects [a plaintiff's] claim for damages according to 
Fuller, in the entire essay there is only a single citation to specific pages from Fuller's work and even then Gardner does not quote anything Fuller actually wrote. ${ }^{15}$ That would not matter much if Gardner had gotten Fuller right, but as I will try to show, he had not. Even this would not matter much if these errors related to marginal aspects of Fuller's work; but Gardner's misinterpretation touches on central aspects of Fuller's view.

To substantiate this claim I first demonstrate the difference between Gardner's Fuller and the real Fuller; and then, through a reconstruction of Fuller's views, I present a challenge to Hart's views. If I am right, neither Hart, nor any of the many who have been sympathetic to his ideas, has adequately answered this challenge.

\section{The Misrepresented Fuller}

Gardner presents the fundamental disagreement between Hart and Fuller as follows:

Lon Fuller had famously claimed that nothing could qualify as a legal system except by (largely) meeting [the] requirements [of legality]. Hart quite rightly denied this in an earlier exchange with Fuller, and he continued to deny it in The Concept of Law. ${ }^{16}$

Fuller never argued for the view that Gardner attributed to him. What he actually said was that a "total failure in any one of [the] eight [principles of legality] does not simply result in a bad system of law; it results in something that is not properly called a legal system at all...." ${ }^{17}$ More intriguingly, and contrary to Gardner's claim, Hart did not deny Fuller's claim, he, at least sometimes, ${ }^{18}$ accepted it: "If social control of this sort [i.e., one based on general standards of conduct communicated to

market share, justice supports that claim. ... But it would be nonsense to suppose that though the law, properly understood, grants her a right to recovery, the value of legality argues against it." Ronald Dworkin, "Hart's Postscript and the Character of Political Philosophy" (2004) 24 Oxford J Legal Stud 1 at 25. Gardner challenges the second of the two sentences (which he quotes in his essay), but the first (which he does not) shows that Dworkin recognizes that legality does not exhaust the morality of law.

${ }^{15}$ There is also a pro forma citation to Lon L Fuller, "Positivism and Fidelity to Law-A Reply to Professor Hart" (1958) 71 Harv L Rev 630, but Gardner does not consider any specific passage from it.

${ }^{16}$ Gardner, supra note 13 at 254 (citation omitted). The "earlier exchange" is, of course, HLA Hart, "Positivism and the Separation of Law and Morals" (1958) 71 Harv L Rev 593 and Fuller, supra note 15. Gardner does not cite a specific page from either source in support of this reading.

${ }^{17}$ Lon L Fuller, The Morality of Law, rev ed (New Haven: Yale University Press, 1969) at 39 (emphasis added).

${ }^{18}$ See Jeremy Waldron, "Positivism and Legality: Hart's Equivocal Response to Fuller" (2008) 83 NYU L Rev 1135 at 1157-60 (showing Hart's vacillations on this issue). 
classes of persons] is to function, the rules must satisfy certain conditions." ${ }^{19}$ And, as it happens, he was not the only prominent legal positivist to do so. ${ }^{20}$

Gardner compounds this misreading of Fuller with another:

Hart fears that people will assume that legality is a property necessarily possessed by all law, and hence that, if legality is an ideal, all law necessarily lives up to it. That is the confusion that Hart plausibly attributes to Fuller. ${ }^{21}$

Gardner cites neither Hart nor Fuller here, and I admit I am not familiar with any work where Hart attributes this claim to Fuller. Most likely this is because it is an extremely implausible claim to hold, and one that is the exact opposite of Fuller's actual view. The heart of the problem lies with the words "if legality is an ideal, all law necessarily lives up to it," which Gardner "plausibly attributes" to Fuller. If that were Fuller's view, he would at the very least be guilty of a rather idiosyncratic, and potentially misleading, use of words. We normally think of ideals as something lived up to only on rare occasions, not something that is always (let alone necessarily) attained. It is odd to attribute such a view to anyone without citation; it is odder still to attribute it to Fuller, for much of the first chapter of The Morality of Law-among those chapters that hardly ever get read-is dedicated to explicating what Fuller calls the "morality of aspiration" (more-or-less, what we now call virtue ethics), which as its name suggests is concerned not with what is necessarily realized, but with what is only attained with "the fullest realization of human powers." ${ }^{22}$ In fact, even in the well-known narrative on King Rex and his failures at law-making, the bulk of the discussion is dedicated to demonstrating the numerous ways in which law can fail to live up to its rule-of-law ideals. A brief comment in a footnote in that chapter contains the following comment: "[Georg] Simmel's discussion is worthy of study by those concerned with defining the conditions under which the ideal of 'the rule of law' can be realized." ${ }^{23}$ That is not what

${ }^{19}$ See HLA Hart, The Concept of Law, 3rd ed (Oxford: Oxford University Press, 2012) at 207 (emphasis added). To fully accept Fuller's view Hart to state that laws that comprehensively fail in their function of guiding behaviour are not just bad laws but are non-laws. Hart never said this, which raises the question, considered in this essay, about the place of these principles in his theory.

${ }^{20}$ Joseph Raz, The Authority of Law: Essays on Law and Morality, 2nd ed (Oxford: Oxford University Press, 2009) at 223 ("It is, of course, true that most of the principles [of legality] cannot be violated altogether by any legal system"); ibid at 226 ("As with some other tools ... a thing is not of the kind unless it has at least some ability to perform its function. ... The law to be law must be capable of guiding behaviour, however inefficiently"); Kramer, supra note 1 at 51-52; Shapiro, supra note 9 at 394-95.

${ }^{21}$ Gardner, supra note 13 at 255.

${ }^{22}$ Fuller, supra note 17 at 5.

${ }^{23}$ Ibid at $39 \mathrm{n} 1$. 
someone who believed that law necessarily lives up to the ideal of legality would write. Other examples are not difficult to find. ${ }^{24}$

\section{The Real Fuller}

What would a more charitable reading of Fuller be? I think it would look roughly like this. The starting point is that the principles of legality are ideals that every legal system should aspire to. This means, as we have seen, that they are not always attainable. Not only are they not always attainable, Fuller believed that because the various principles of legality sometimes conflict, it may be undesirable to try to pursue them to the full. Though Fuller defended (the historically plausible) claim that lack of concern for the principles of legality is often accompanied by (and perhaps leads to) more comprehensive moral failure, he was also keenly aware of the fact that on occasion the desire to pursue the principles of legality may come into conflict with the substantive aims of the law. ${ }^{25}$ In other words, contrary to Gardner's suggestion that Fuller failed to notice that legality has costs, Fuller recognized two distinct reasons why we may sometimes want less legality rather than more.

This, then, is not where Hart and Fuller had their disagreement. The crucial point for Fuller, and the one that is completely absent from Gardner's account, is that the considerations that make up the principles of legality are not merely law's ideals; they are also its grounds. They are grounds in the sense that widespread failure to maintain these standards above a certain minimal level results in something "not simply bad law, but not law at all." ${ }^{26}$ Let me explain.

Gardner describes Fuller as holding the view that "law is []sufficient for legality," 27 that is, that wherever there is law, there is, ipso facto, legality. He describes this as the view that there is "one step" between non-law and law-withthe-ideal-of-legality-necessarily-realized. The view Gardner attributes to Fuller follows from the way he characterizes Fuller's position. As we have seen, according to Gardner's Fuller, to be law something must largely satisfy the requirements of legality, and when this happens law necessarily lives up to its ideal. Gardner contrasts this with the view he attributes to Hart (and which he takes to be correct)

${ }^{24}$ See e.g. ibid at 157 ("law is a precondition for good law," but the two are not identical); Lon L Fuller, "The Forms and Limits of Adjudication" (1978) 92 Harv L Rev 353 at 357 ("attempt[ing] to define 'true adjudication,' or adjudication as it might be if the ideals that support it were fully realized"). For a general discussion of the place of ideals in Fuller's legal philosophy see Kenneth I Winston, "The Ideal Element in a Definition of Law" (1986) 5 Law \& Phil 89 especially at $108-09$.

${ }^{25}$ Fuller, supra note 17 at 92 ; Fuller, supra note 15 at $655-56$.

${ }^{26}$ Fuller, supra note 17 at 197.

${ }^{27}$ Gardner, supra note 13 at 257. 
according to which there are two steps. The first step is the move from non-law to law and the second is the move from bare law to law-with-legality.

The preceding discussion shows, however, that Fuller too is a two-step theorist. The difference between Hart and Fuller lies in the content of those steps. Fuller believed that some of the factors required for the second, excellence, step are also relevant, at much lower levels of attainment, for the first, threshold, step. (Are they the only relevant considerations for this first step? Probably not, but Fuller does not talk much about this.) In spelling out his principles of legality Fuller says:

So far we have been concerned to trace out eight routes to failure in the enterprise of creating law. Corresponding to these are eight kinds of legal excellence toward which a system of rules may strive. What appear at the lowest level as indispensable conditions for the existence of law at all, become, as we ascend the scale of achievement, increasingly demanding challenges to human capacity. ${ }^{28}$

This view may be false, but there is nothing crazy about it. To give an example from a different domain, some of the factors relevant to making a novel a great thriller (for instance, ample doses of suspense) are also factors that if completely absent would disqualify it from being a thriller at all.

Once Fuller's real position is acknowledged, it is Hart's view that appears surprising, or at least incomplete. It is surprising because it suggests that the considerations relevant for the first step-Hart's secondary rules-are utterly different from the factors relevant for the second step-the principles of legality. While this view is logically possible, it appears odd without further argument, and one that Hart never provides. Consequently, even if a convincing explanation for this claim can be made out, Hart's failure to address it renders his account seriously, devastatingly, incomplete. And despite enormous literature on virtually every aspect of Hart's work, this point (as far as I know) received scant attention: Hart claims that it is the addition of secondary rules of recognition, adjudication, and change to the primary rules of obligation that moves us from the pre-legal to the legal domain. What Hart never explains is why it is these particular secondary rules and not anything else that matters for the first step into the legal domain. Even if we accept that law is a matter of rules, and even that it is a "union" of different kind of rules that marks the entry into the legal world, Hart does not explain why it is the particular secondary rules he mentioned and not others that are essential for constituting law, why it is just the secondary rules he mentioned and not some additional ones (e.g., enforcement rules), or why a legal system cannot exist with fewer secondary rules.

This is not a minor quibble. The "union or primary and secondary rules" is the heart of Hart's theory, and the gap in his account makes it difficult to understand how we can tell whether he is right; in addition, it makes it difficult to tell whether

${ }^{28}$ Ibid at 41 (emphases added); see also ibid at 42 ("The inner morality of law ... embraces a morality of duty and a morality of aspiration"). 
there is anything that could, even in principle, show him wrong. Suppose someone insisted after hearing Hart's account that something could be a legal system even if it only had primary rules, what would Hart say in response? It is remarkable that on such a central aspect of his theory Hart said virtually nothing. Hart did say that a union of primary and secondary rules can address all kinds of problems that a regime made up exclusively of primary rules could not. But just as Hart said that by claiming that unjust law is not law the natural lawyer fused (and thus confused) two distinct issues, one could say the same of Hart's account. By building into his account of what counts as law factors that have to do with law's efficiency, Hart made it difficult to distinguish between a bare legal system made up of primary rules alone, and a more efficient legal system that supplements them with secondary rules. Consequently, Hart's account makes it difficult to distinguish between mere law and (more) efficient law.

Perhaps, one might reply, I am overtheorizing a simple point. Hart succeeded in capturing and articulating our intuition as to what counts as law. He did not offer any further explanation on this point, because there was no explanation to offer. If someone succeeded in providing an account of what counts as a chair, it would make no sense to ask why it is the properties he identified and not others that count for something being a chair. Such accounts can only be challenged if they are wrong, but as it happens, Hart was right.

This answer would be disastrous for Hart's project. ${ }^{29}$ Even if we grant for the sake of argument that law is like a chair in this regard, one would still wish to know in virtue of what we can know whether Hart got it right. If the concept of law is not an idea floating in some heaven of concepts, if Hart's claim is that he has identified the true contours of a familiar social practice, it would make sense to check whether he has succeeded in his account by examining his claim against the social group which uses this social practice, namely all people. If Hart's account is nothing more than an explication of an intuition, why should we not conduct a survey to see whether his intuition is shared with others? The comparison with chairs is helpful here: we may not ask someone who offered us an explication of what a chair is for an explanation of why this was so, but we would definitely consider it a challenge to her account if we found out that her account did not correspond to the way (most) people used the term. Hart may have convinced some other legal theorists of the correctness of his account, but perhaps legal theorists, because of their close engagement with the law, are an unrepresentative group on such matters. And as it happens, we know that Hart's intuition is not shared even by all

${ }^{29}$ Hart himself, as it happens, would have rejected this answer. See Hart, supra note 19 at 215 (unlike "the allotment of proper names [like London] ... the extension of the general terms of any serious discipline is never without its principle or rationale.... When [it is asked] 'We know that it is called law, but is it really law?', what is demanded ... is that the principle be made explicit and its credentials inspected."). 
legal philosophers, so we have little reason to feel confident that he has successfully captured what most people mean by law. If that is not the standard against which the correctness of his theory may be assessed, what is?

Put differently, if all one offers in support of the claim that it is Hart's secondary rules that move us from the prelegal to the legal are his intuitions, he has no argument against those who reject his account. On this interpretation his account ultimately rests on an unanalyzable intuition ("that is just what law happens to be"), but then so do his critics' conflicting accounts. As their unanalyzable intuitions are no less valid than his, nothing Hart has written can show them wrong. Indeed, if that is what validates Hart's account nothing he could have written (short of pointing to contradictions in his interlocutors' work) could show them wrong.

Here is a concrete example: Hart criticized John Austin's command theory for failing to distinguish between law and the gunman situation writ large. ${ }^{30}$ But what is it exactly that distinguishes the gunman situation writ large-the mafiacontrolled town, say-from law? Hart thought there is a real normative difference between the two, captured in the difference between "being obliged" and "being under an obligation." Setting aside the fact that this argument rests on an empirical claim about linguistic usage for which Hart has provided no evidence whatsoever, Hart has to address the crucial question why people use these different linguistic formulas with regard to the gunman and law, respectively. One answer that as a historical matter many philosophers found persuasive is that law is, at least potentially, committed to justice. As Augustine famously put it: "Remove justice, and what are kingdoms but gangs of criminals on a large scale?" ${ }^{31}$ A putative legal system flourishes when it succeeds in promoting justice; when it utterly fails in doing so, or worse, when it subverts it, it no longer counts as a legal system at all: it becomes something that bears some superficial semblance to law, but really is not different from the acts of the gunman, only writ large.

This answer is, of course, not available to Hart. Assuming the different elements of his account are consistent, the conclusion we must draw is that the reason why the gunman situation writ large is not one of law is that it lacks secondary rules. But without an explanation as to why his claim that it is the addition of the secondary rules that moves us from the domain of "being obliged" to the domain of obligation remains a mere assertion and not something that could convince anyone not already committed to this view.

Actually, even on the basis of Hart's own premises this view is not very plausible, because we do not think secondary rules are required for the existence of

${ }^{30}$ Ibid at $19-24,82-85$.

${ }^{31}$ Augustine, The City of God, Henry Bettenson trans. (London: Penguin, 2003) at 139 (§iv.4); cf Fuller, supra note 15 at 632. Hart, supra note 19 at 156, quotes Augustine's words (in a different translation), but incorrectly cites Augustine's Confessions. 
moral and social obligations. It is true that Hart insisted that legal and moral obligations are distinct and different, but nothing he has ever said explains why secondary rules are needed for the existence of one kind of obligation and not for the other. The problem here is that the more different are legal and social obligations from each other, the less transferable is the distinction between "being obliged" and "being under an obligation" (made in the context of social or moral obligations) to the domain of legal obligations. Without more, to just say that legal and social obligations are different in their existence conditions but are similar in what they mean once they come into existence, looks rather ad hoc.

If all we have are equally valid competing intuitions that are backed up by assertions that convince those already convinced, there is no point in the debate. All that Hart's defenders can say is that they share his intuition on the matter; Hart's detractors could similarly assert that they have a different intuition, one that they share with Augustine. Thus, an unintended consequence of the suggestion that Hart simply discovered a fundamental, unanalyzable truth about law is that legal philosophy has to be understood as one of two things. It is either "descriptive sociology" on what people classify as law, a kind of empirical investigation into prevailing meaning only without any empirical evidence in support of its claims; or it is a debate that hangs on the truth of competing intuitions that by definition cannot be challenged by argument.

Are these the only possibilities? I think there are two more, but unfortunately they are no more attractive. The first appears late in The Concept of Law. If early in the discussion of natural law theory the impression one gets is that Hart thinks natural law theory is simply wrong, towards the end of Chapter IX, Hart concedes that the natural law story is possible and coherent. In the terminology used here, Hart concedes that at the level of intuition, both the positivist and the natural law intuitions are possible, and neither can show the other is demonstrably false. $\mathrm{He}$ then explains his preference for the narrower, positivist, concept of law by its greater explanatory power. ${ }^{32}$ As already mentioned, this concession can be directed back at Hart to undermine his claim that law comes into being when we have a union of primary and secondary rules. It is, however, devastating to Hart's enterprise in a more general and fundamental way. By making it, Hart abandons the claim that jurisprudence is primarily a conceptual inquiry and reframes the debate between legal positivism and natural law as a normative debate, in which different sides try to convince each other to adopt a certain view of law. This a radical shift. After all, Hart has sought to describe the concept of law, and his account of law as the union or primary and secondary rules was premised on this idea that with it he has identified "two minimum conditions necessary and sufficient for the existence of a legal system." ${ }^{33}$ If the natural law story is possible, then clearly this claim is false,

\footnotetext{
${ }^{32}$ Hart, supra note 19 at $210-14$.

${ }^{33}$ Ibid at 116.
} 
because the debate between legal positivism and natural law can no longer be treated as a conceptual one. Hart's concession implies that the debate is normative, perhaps not in the sense of what it would be better to do, but in terms of what it would be better to believe. ${ }^{34}$

The remaining possibility is that the move from the prelegal to the legal that Hart described, makes sense from a certain socio-political perspective. Put more bluntly, on this interpretation Hart did not describe a universal truth about what makes something into law; at best what he did was articulate the idea of law as understood in a particular place and time, and especially for a particular group committed to certain political values. I think there is much to be said in support of a reading of Hart that shows that in spite of his disavowal, his account of the nature of law is much more local and temporal than he purported it to be. As this is not the topic of this essay I will not spend time on substantiating this claim. ${ }^{35}$ I will only state that what the addition of the secondary rules does to the normative order of primary rules alone makes sense from within a particular moral conception that, first, puts (negative) liberty and autonomy at its heart and, second, has the social environment of the modern state as its background. We need a "rule of recognition," for example, in order to know what the law requires of us, only when the law can no longer be understood as the articulation of existing custom, common sense morality, or as the collective wisdom of the ages-all ideas associated with law in premodern and early modern times. In the modern state when it no longer makes sense to describe the content of much of the law in these terms, the need for an easy means for knowing what the law requires becomes acute; its absence is then a challenge to the very existence of law because of its potential for undercutting individual autonomy.

Gardner recognizes that Hart is open to this charge, but suggests that the problem with Hart's account has more to do with poor phrasing than with substance. "Hart should have made clear," he says, that the "secondary rules ... do not automatically bring with them the rule of law" and that "their arrival is not necessarily to be welcomed." 36 Their arrival only brings with it law, not law-withlegality, and there may be times in which bare law may be worse no law. I do not find this answer sufficient to address the challenge just raised. Gardner takes the

${ }^{34}$ Not surprisingly, Gardner disagrees with Hart on this point. Gardner, supra note 13 at 259. Hart himself seems to have backtracked from this idea in the Postscript to the book. See Hart, supra note 19 at 239-40.

${ }^{35}$ I do elaborate on this point in a somewhat different context in Dan Priel, "Is There One Right Answer to the Question of the Nature of Law?" in Wil Waluchow \& Stefan Sciaraffa (eds), Philosophical Foundations of the Nature of Law (Oxford: Oxford University Press, 2012) 322 at 325-27, 331-36, and Dan Priel, "Are Jurisprudential Debates Conceptual? Some Evidence from Democratic Theory" (2012) 50 Osgoode Hall LJ 359 at 364-77 [Priel, "Jurisprudential Debates"].

${ }^{36}$ Gardner, supra note 13 at 256-57. 
challenge to be, essentially, what he takes his reading of Fuller to be. But that is, as we have seen, an unlikely way of understanding this challenge. A better one is that the function of the secondary rules is to solve certain particular moral problems, something that presupposes a certain social environment and certain political values. Saying this does not imply that these functions are necessarily handled well, nor does it imply that even if handled well, all other moral problems automatically get solved with it, but it does show that the rule of recognition is there to address moral problems that arise in a particular social-political context, and that it is for these reasons that the rule of recognition is deemed crucial for the existence of law in the conditions of the modern world.

If this is correct, the reason why many legal philosophers found Hart's account appealing is because he succeeded, perhaps inadvertently, in capturing something about law of their time. If this is indeed the case, however, Hart's ideas lose their philosophical aspirations and become a kind of abstract sociology in the vein of Max Weber. This may not be a bad thing (although it bears reminding that Weber did bother to support his arguments with a wealth of empirical evidence), but it means that those who have followed Hart (and perhaps Hart himself) have misunderstood his achievement. Perhaps more worryingly for Hart, this interpretation of his work does nothing to answer the claim that the factors relevant for the move from the prelegal to the legal have nothing to do with law's excellences. Quite the contrary, on this interpretation it is Fuller and his principles of legality that explain why the rule of recognition is so central to Hart's theory.

To sum up, on the basis of Fuller's work I have raised the question in virtue of what Hart's account is true (if it is). I have presented four possible answers to the question: an empirical claim about what people mean by law, an unanalyzed and unanalyzable intuition about what makes something into law, a normative choice between two possible explanations made on explanatory grounds, or an abstract account of what makes something into law in the modern Western world. My argument has been that Hart is very unclear on which of these is the right one and that each interpretation poses serious difficulties to his overall account.

Against this background, Fuller's account comes out as superior, exactly because Fuller makes it clear that it is not a purely conceptual argument, but a political one, and one that may be limited to the conditions of the modern state. ${ }^{37}$ Fuller presented his view as the conclusion of a normative inquiry into what the ideal form of law is (or perhaps what one ideal form of law is). With the addition of the relatively modest assumption that the considerations relevant to the ideal step are also relevant for the threshold step, he could explain why significant failure in complying with the precepts of legality can lead to something that is not law. (This, incidentally, is one way of making sense of Fuller's otherwise puzzling claim noted briefly earlier, that in the domain of purposive activity the divide between is and

\footnotetext{
${ }^{37}$ Fuller, supra note 17 at 205, 234.
} 
ought is illusory.) At least if one accepts that law is in the business of guiding people ${ }^{38}$ it is perfectly plausible to derive from this not just an account of what it means for law to do this well, but also an account of what it means for law to exist.

That does not yet show that Fuller's account is successful, but it presents a coherent, arguable, view, which has "structural" advantages over Hart's. A further strength of his account is that it has an explanation for why failing to maintain the principles of legality is a kind of moral failure, and why keeping these principles is a kind of moral achievement. This is not the familiar, simple, claim that the principles of legality are a kind of morality, one that many legal positivists have found uncongenial. Fuller's reason rarely gets mentioned, but it is a crucial ingredient of his position. Fuller argues that because law is created by humans for humans, and because it imposes practical demands on them, it must do so in a manner that takes their personhood, their agency, into account. Thus, the principles of legality make a normative difference to the way the demands are made, and this difference may be necessary (although not sufficient) for making these demands legitimate. The "view of man" underlying this account of law, Fuller says, is that one "is, or can become, a responsible agent, capable of understanding and following rules, and answerable for his defaults." 39 It is this relation that creates a "bond of reciprocity" that "ground[s] the citizen's duty to observe the rules." ${ }^{40}$ All this does not yet guarantee that what is being demanded will be good, so it is by no means the whole of the morality relevant to law. But these demands make a difference that is relatively independent of the content of the laws, and as such applicable to law in general. In this way, yet again, Fuller's position can provide an answer to a puzzle about Hart's ideas where Hart offered none. We have seen that Hart had no answer to the question why the gunman situation was qualitatively different from law. One could summarize Fuller's view as the claim that having law requires taking the personhood of its subjects seriously, and that this is what the gunman situation, large or small, lacks.

How effective is this argument against not just Hart but those who consider themselves Hart's followers? In a striking change, it has become almost a shibboleth of contemporary legal positivism that law necessarily has moral aims, thereby

${ }^{38}$ This idea is accepted by virtually all contemporary legal positivists. For example see $i d$. at 258 , where Gardner says that the "telos [of rules] as rules ... is to guide." The idea that a primary function of law is guidance is accepted by most contemporary legal positivists. Other examples are cited in Priel, "Jurisprudential Debates," supra note 35 at 364 n 8.

${ }^{39}$ Fuller, supra note 17 at 162 . It is for this reason that I agree with Gardner that there is "confusion" in describing this, or any, conception of the rule of law "formal." See Priel, "Jurisprudential Debates," supra note 35 at 382-84. Gardner places the blame for this confusion on a 1997 essay by Paul Craig. See Gardner, supra note 13 at 263 n 46. The fault, however, probably lies with Raz's 1977 essay on the rule of law: "It is evident," Raz says of his own view, "that this conception of the rule of law is a formal one." Raz, supra note 20 at 214.

${ }^{40}$ Fuller, supra note 17 at 40; see also ibid at 204. 
establishing a necessary connection between law and morality. ${ }^{41}$ But if law necessarily has a moral aim, it should be explained why something that has the appearance of law, but utterly fails in attaining that aim- either because of its content, or more narrowly because of the Fullerian argument presented here-still qualifies as law. More precisely, the contemporary positivist faces a dilemma, both horns of which can be traced to Fuller's work: If the attribute of moral aim is based on something that is in principle identifiable in the intentions of those engaged in the practice, then the claim is open to the charge that like in many other human endeavours intentions do not always suffice for success. Spectacular failure in living up to an aim may result in something that is not just a bad specimen of what one tried to create, but something that does not qualify as a specimen at all. (Compare: that one attempts to write a thriller is not enough for producing one, even a bad one.) If, on the other hand, this moral aim is an attribute that cannot be identified in this way, then the claim has nothing to support it; it is merely an assertion. If we wish to designate a certain phenomenon as "law," we can say that it has the moral aim (necessarily) only it fails in fulfilling it; if we do not, we can say that it is not law because it does not have that moral aim. Since there is nothing either in the practice itself (which by definition can utterly fail in living up to the ideal) or in the intentions of the lawmaker (which by hypothesis are irrelevant for this question), to aid in answering this question, then on this interpretation there is nothing on which this claim can be confirmed or refuted. Though I cannot show this here, I think the irrefutability of this claim is symptomatic of a larger problem, the emptiness of the attempt to distinguish between law and non-law outside of a normative political framework. ${ }^{42}$

\section{Doing Fuller Justice}

Does this amount to a serious problem for legal positivism? To answer this question it would help to present Fuller's position in syllogistic form. The typical understanding of Fuller's argument looks something like this:

(1) Some compliance with the principles of legality is necessary for law's existence.

(2) The principles of legality are moral.

${ }^{41}$ In slightly different formulations this view is adopted in Gardner, supra note 13 at 254; Joseph Raz, Between Authority and Interpretation: On the Theory of Law and Practical Reason (Oxford: Oxford University Press, 2009) at 176-78; Jules L Coleman, "The Architecture of Jurisprudence" (2011) 121 Yale LJ 2 at 52-53; Shapiro, supra note 9 at 213-15; Green, supra note 4 at 1050 .

${ }^{42}$ For more on this last point see Dan Priel, "The Place of Legitimacy in Legal Theory" (2011) 57 McGill LJ 1 at 10-14. 
Hence: (3) there is some necessary connection between law and morality, and therefore legal positivism is false.

There are many ways of responding to this argument. As we have seen, many legal positivists have accepted (1) but denied (2). Some legal positivists, on the other hand, have accepted (2) but rejected (1). ${ }^{43}$ (Gardner seems to want to reject both (1) and (2), although the matter is somewhat unclear because what he rejected was not (1), but a different claim, which Fuller did not make.) It is also possible to deny that (1) and (2) entail (3), a claim made possible by the fact that the term "necessary connection" is so ill-defined in jurisprudential literature, that it is difficult to be sure what the term "necessary connection between law and morality" even means. Yet another possible response is to deny that the existence of a necessary connection between law and morality (however such a connection is defined) marks the dividing line between legal positivism and non-positivism. As already mentioned, the latter approach has been popular among legal positivists in recent years.

In this essay I avoided the question of the relation between the principles of legality and morality, as well as the question of the "necessary connection." What I have sought to show instead is that Fuller's position reveals a fundamental and unanswered difficulty in Hart's version of legal positivism: Hart lacks an argument explaining why a legal system emerges in the circumstances he described, and the fact that he has no explanation as to why the factors he concedes are relevant for law's excellence are irrelevant for its existence. This is particularly troubling for contemporary legal positivists like Andrei Marmor, who tell us that the "truth of legal positivism is simply not at stake" in debates about the principles of legality, because legal positivism is only concerned with the question of the conditions of legal validity. ${ }^{44}$ Fuller's challenge as presented here asks legal positivists to explain exactly why the principles of legality are irrelevant to the question of legal validity.

This is enough to show that Fuller (or a reconstruction of his views) presents legal positivists with a case to answer, one that cannot be brushed off as easily as they seem to think. But that is, I think, only part of the story. The most significant criticism Fuller deserves in his exchange with Hart, it is for not taking his critique of Hart's approach far enough, for not making its real point clearer. In parts of The Morality of Law Fuller gives the impression that Hart correctly identified the task of jurisprudence and the only disagreement he has with Hart is over a narrow question within this framework. Perhaps he did this only for tactical reasons, to narrow down the scope of his disagreement with Hart for the sake of what he

\footnotetext{
${ }^{43}$ For an example see Andrei Marmor, "The Rule of Law and Its Limits" (2004) 23 Law \& Phil 1.

${ }^{44}$ Ibid at 41.
} 
hoped would be a more fruitful exchange. ${ }^{45}$ If that is the case, in doing so Fuller may have inadvertently contributed to his view's relative demise, as it ended up looking like a kind of unsatisfactory halfway house between Hartian positivism and a more committed natural law view.

Against the view that Fuller merely disagreed with positivists on the conditions of legal validity, a sympathetic reading of Fuller's work suggests that his real challenge to legal positivism ran much deeper. This is particularly clear when taking into account what Fuller said outside The Morality of Law, or even what he added to the book in his 1969 "Reply to Critics." Fuller's ideas make more sense if we understand him arguing that there is no answer to the question of the "nature of law," if that inquiry is understood as a purely conceptual inquiry. ${ }^{46}$ To the extent that the search for the conditions of legal validity is part and parcel of that conceptual inquiry (and I think it is), ${ }^{47}$ its most fundamental problem is that it derives from a mistaken approach to jurisprudence.

If this is true, Fuller's more complete argument against legal positivism, and fuller understanding of his theory of law, is yet to be presented. Whatever the truth on this matter may be, what I have tried to show is that even within a discussion of much narrower scope one can reconstruct from Fuller's work a clear and powerful argument against Hart's work, as well as more broadly against work inspired by him. In my reconstruction this tradition makes two assumptions. One is that the normative considerations that go into evaluating law's excellence are different from the conditions of its existence; the other is that the considerations that go into law's existence are non-evaluative. ${ }^{48}$ (I ignore here the complication possibly brought in by inclusive legal positivism, as it does not affect the main point.) The second assumption is familiar, but placing it next to the first one shows just how odd it is and what extra baggage one must take on in order to defend it. That a view looks

${ }^{45}$ There is some evidence that Fuller did not place much significance and was not personally very interested in these questions. See Winston, supra note 24 at 91 , quoting a letter from 1972 that Fuller sent Samuel Mermin, in which Fuller writes: "I am not concerned with offering precise definitions of legal phenomena, but with analyzing the basic processes that constitute an entity of somewhat vague outlines that we call 'a legal system." See also Fuller, supra note 17 at 242, where he expresses the hope "legal philosophers will cease to be preoccupied with building 'conceptual models' to represent legal phenomena."

${ }^{46}$ Cf Kristen Rundle, Forms Liberate: Reclaiming the Jurisprudence of Lon L Fuller (Oxford: Hart, 2012) at 59, 78. I ultimately differ in my strategy of "reclaiming" Fuller's jurisprudence. Rundle seems to think that the right way to do so is by showing how Fuller's work can be shown to be engaged in "conversation" with contemporary jurisprudential discourse. See ibid at 78-84, chs 6-8. In my view, this approach tames Fuller's ideas and plays into the hands of his critics.

${ }^{47}$ See Priel, supra note 42 at 29-30.

${ }^{48}$ For an example of these two assumptions, stated but not defended, see Marmor, supra note 7 at $133-34$. 
odd does not yet show it to be false, and perhaps further argument will show that it is in fact true. What I hope to have shown is that a fair reading of Fuller illustrates the urgency, almost fifty years after The Morality of Law was published, of addressing this problem that Fuller raised. 